\title{
HUBUNGAN BEBAN KERJA DAN EFIKASI DIRI DENGAN BURNOUT PADA ANGGOTA SATUAN BRIGADE MOBILE KEPOLISIAN DAERAH SUMATERA UTARA
}

\author{
Oleh
}

Fahruroddin

Email: farellfahrudin@gmail.com

Magister Psikologi Universitas Medan Area

\begin{abstract}
This study aims to determine the relationship between workload and self-efficacy with burnout. The study was conducted at the mobile brigade police of the Republic of Indonesia North Sumatra. The number of respondents in this study were 196 members of the mobile brigade with non probability sampling techniques. Based on Spearman rank data analysis obtained a significant level between workload with burnout with a significant value of $0,000<0,05$, meaning that there is a partial relationship between workload and burnout. While the relationship of self-efficacy with burnout with a significant value of $0,000<0.05$. This proves that there is a partial relationship between self efficacy and burnout. While the significance level of the workload and self efficacy with burnout with a significant value of $0,000<0,05$ are related simultaneously, then the hypothesis in this study is accepted. The correlation between workload and self efficacy with burnout on members of the mobile brigade, North Sumatra is $90 \%$. The conclusions of this research are workload and self efficacy have relationship significant with burnout.
\end{abstract}

Keywords: Burnout, workload, self-efficacy.

Abstrak. Penelitian ini bertujuan untuk mengetahui hubungan beban kerja dan efikasi diri dengan burnout. Penelitian dilaksanakan di satuan brigade mobile kepolisian daerah Sumatera Utara. Jumlah responden dalam penelitian ini adalah 196 anggota satuan brigade mobile dengan teknik pengambilan sampel non probability sampling. Berdasarkan analisis data rank spearman diperoleh taraf signifikan antara beban kerja dengan burnout dengan nilai signifikan $0,000<0,05$, artinya membuktikan bahwa terdapat hubungan secara parsial beban kerja dengan burnout. Sedangkan hubungan efikasi diri dengan burnout dengan nilai signifikan $0,000<0,05$. Hal tersebut membuktikan bahwa terdapat hubungan secara parsial konsep diri dengan burnout. Sedangkan taraf signifikasi beban kerja dan efikasi diri dengan burnout dengan nilai signifikan 0,000<0,05 berhubungan secara simultan, maka hipotesis dalam penelitian ini diterima. Besar korelasi hubungan beban kerja dan efikasi diri dengan burnout pada anggota satuan brigade mobile kepolisian daerah Sumatera Utara sebesar 0.90\%. Kesimpulan penelitian ini adalah beban kerja dan efikasi diri berhubungan signifikan dengan burnout.

Kata Kunci: Burnout, beban kerja, efikasi diri.

20 | Psychophedia Jurnal Psikologi Universitas Buana Perjuangan Karawang 


\section{Pengantar}

Menurut Pangastiti (2011) burnout merupakan perubahan sikap dan perilaku dalam bentuk reaksi menarik diri secara psikologis dari pekerjaan, seperti menjaga jarak dari orang lain maupun bersikap sinis dengan mereka, membolos, sering terlambat dan keinginan pindah kerja sangat kuat. Dale (dalam Rizqiansyah, 2017) menyatakan bahwa kejenuhan kerja menjadi masalah bagi organisasi bila mengakibatkan penurunan kinerja dan produktivitas. Rizqiansyah (2017) menyatakan bahwa burnout menggambarkan kondisi emosional seseorang yang merasa lelah dan jenuh secara mental, emosional, dan fisik akibat tuntutan kerja yang meningkat. Menurut Ivancevich dkk (2005) burnout adalah suatu proses psikologis yang dibawa oleh stres pekerjaan yang tidak terlepaskan, menghasilkan kelelahan emosi, perubahan kepribadian, dan perasaan penurunan pencapaian.

Maslach (dalam Rahman, 2007) berpendapat bahwa burnout memiliki pengertian multidimensional, berupa sindrom psikologis yang terdiri dari tiga aspek, yaitu: (1) kelelahan emosional, (2) depersonalisasi, dan (3) low personal accomplishment. Menurut Pines dan Aronson (dalam Tetrich \& Quich, 2002) burnout terdiri dari tiga aspek, yaitu: 1). Kelelahan fisik, yaitu suatu kelelahan yang dapat dilihat pada gejala-gejala sakit fisik dan berkurangnya energy fisik pada seseorang. 2). Kelelahan emosional, yaitu suatu kelelahan pada individu yang berhubungan dengan perasaan pribadi yang ditandai dengan rasa tidak berdaya. 3). Kelelahan mental, yaitu suatu kondisi kelelahan pada individu yang berhubungan dengan rendahnya penghargaan diri sendiri.

Hasil wawancara yang dilakukan kepada pihak sumber daya manusia, ditemukan perilaku negatif pada anggota brigade mobil seperti a). Dari sisi emosional yaitu memiliki rasa bosan, suka mengeluh, mudah tersinggung, suka marah dan tidak peduli. B). Sisi mental yaitu kurang bersimpati dan egois. C). Segi fisik yaitu sering sakit, sinis, susah tidur, dan lain-lain. Para anggota Brimob juga mengaku, bahwa kelelahan yang mereka alami juga disebabkan oleh tuntutan pekerjaan yang tinggi, jadwal libur yang tidak menentu, dituntut siap dan sigap jika terjadi permasalahan secara tiba-tiba di wilayah Negara Indonesia. Beberapa anggota juga menambahkan bahwa dirinya kerap kali putus asa, mengabaikan kualitas hubungan dengan teman sekerjanya, hingga pada akhirnya anggota BRIMOB tersebut tidak memiliki kemampuan untuk mencapai suatu tujuan tertentu.

\section{Landasan Teori}

Beban Kerja

Menurut Sari (2015) beban kerja merupakan intensitas pekerjaan yang meliputi jam kerja, jumlah individu yang harus dilayani, serta tanggung jawab yang harus dipikul. Beban kerja secara kualitatif dilihat dari kesulitan pekerjaan tersebut untuk dikerjakan. Hart dan Staveland (dalam Prijayanti, 2015) mendefinisikan beban kerja sebagai perbedaan antara kemampuan karyawan dengan tuntutan tugas yang di terima. Beban kerja itu dapat berupa beban kerja fisik dan beban kerja mental. Everly (dalam Munandar, 2001) mengatakan bahwa beban kerja adalah keadaan dimana pekerja dihadapkan pada tugas yang harus diselesaikan pada waktu tertentu.

Menurut Cooper (dalam Munandar, 2001) secara spesifik, beban kerja dapat dibagi dua, yaitu beban kerja fisik dan mental. Beban fisik cenderung mengarah 
pada beban yang diterima seorang karyawan dalam suatu pekerjaan yang berkaitan dengan kondisi fisiologisnya, seperti kebisingan, vibrasi (getaran), dan hygiene. Apabila kondisi kerja yang demikian cukup buruk, maka akan terjadi stres kerja dengan gejala fisikal, seperti tekanan darah tinggi, diare, obstipasi, dan lain-lain.

Beban kerja yang dialami oleh anggota akan berdampak pada penampilan kinerja anggota. Penelitian yang dilakukan oleh Sari (2015) pada perawat pelaksana ruang intermediet RSUP Sanglah, menemukan bahwa terdapat hubungan yang signifikan antara beban kerja dengan burnout syndrome. Penelitian yang dilakukan oleh Rizqiansyah di PT. Jasa Marga (PERSERO) menemukan bahwa beban kerja fisik dan beban kerja tidak dapat memprediksi terjadinya kejenuhan kerja (burnout) pada karyawan sehingga dimungkinkan banyak faktor lain yang dapat mempengaruhi terjadinya kejenuhan kerja (burnout).

\section{Efikasi Diri}

Menurut Bandura (1997) self-efficacy merupakan keyakinan individu mengenai kemampuan dirinya dalam melakukan tugas atau tindakan yang diperlukan untuk mencapai hasil tertentu. Self-efficacy ini dapat menggerakkan motivasi, kemampuan kognitif, mengurangi ketegangan emosi dan tindakan, yang diperlukan untuk memenuhi tuntutan situasi. Sehingga ketika seseorang memiliki efikasi yang rendah, dia akan kurang mampu untuk menghadapi suatu masalah atau tugas tertentu. Menurut Bandura (1997) reaksi stres pada seseorang, terjadi karena rendahnya self-efficacy orang tersebut untuk mengontrol ancaman dari lingkungan yang tidak menyenangkan, sehingga ketika dihadapkan dengan situasi yang kurang menyenangkan, mereka tidak mampu berfungsi dengan baik.

Baron dan Byrne (2003)

mengemukakan bahwa self-efficacy merupakan penilaian individu terhadap kemampuan atau kompetensinya untuk melakukan suatu tugas, mencapai suatu tujuan dan menghasilkan sesuatu. Schultz (dalam Hartawati \& Mariyanti, 2014) mendefinisikan self-efficacy sebagai perasaan kita terhadap kecukupan, efisiensi, dan kemampuan kita dalam mengatasi kehidupan. Menurut Woolfolk (2004), selfefficacy adalah penilaian individu terhadap dirinya sendiri atau tingkat keyakinan mengenai seberapa besar kemampuannya dalam mengerjakan suatu tugas tertentu untuk mencapai hasil tertentu.

Aspek-aspek efikasi diri menurut Bandura (dalam Sulistyawati, 2010) adalah a). kekuatan, yaitu Individu yang memiliki level yang tinggi merasa bahwa dirinya memiliki kemampuan menguasai permasalahan yang sulit, sedangkan individu yang memiliki level yang rendah meyakini bahwa dirinya hanya mampu menyelesaikan tugas-tugas yang sederhana.generalisasi dan tingkatan.

\section{Metode Penelitian}

Penelitian ini menggunakan desain kuantitatif non-eksperimental, yang dilakukan di satuan brigade mobile Sumatera Utara yang beralamat di jalan K.H. Wahid Hasyim No. 3i, Medan Baru Kota Medan. Populasi dalam penelitian ini adalah 400 orang dengan sampel penelitian 196 anggota Brimob. Teknik pengambilan sampel yang digunakan dalam penelitian ini mengacu pada teknik non probability sampling.

Dalam penelitian ini pengumpulan data yang digunakan adalah melalui alat ukur: 
1. Skala burnout, yaitu diadaptasi dari teori Maslach \& Jackson (dalam Cooper, Schabarcq, \& Winnubust, 1996), yaitu: kelelahan emosional, depersonalisasi, dan reduced personal accomplishment.

2. Skala beban kerja, yaitu diadaptasi berdasarkan aspek-aspek dari Hart dan Staveland (dalam Prijayanti, 2015), yaitu: physical demand, effort, mental demand, temporal demand, performance, frustation level.

3. Skala efikasi diri, diadaptasi berdasarkan aspek-aspek dari Bandura (1997), yaitu: tingkatan (level), keluasan (generality) dan kekuatan (strength).

Semua alat ukur diuji coba terhadap 30 orang anggota Brimob untuk melihat kevalidan dan reliabilitas alat ukur.

\section{Hasil Dan Pembahasan}

Berdasarkan hasil pengujian hipotesis pada uji korelasi Product Moment menggunakan SPSS menunjukan bahwa pada variabel beban kerja (X1) nilai koefisien korelasi (rxy) sebesar 0.414 dan nilai signifikansi (p) sebesar $0.000<0.05$. Hal ini menunjukan bahwa terdapat hubungan secara parsial variabel beban kerja (X1) dengan variabel burnout anggota Brimob (Y). Hasil ini menunjukkan bahwa hipotesis pertama yang berbunyi "ada hubungan beban kerja dengan burnout", dapat dinyatakan terbukti kebenarannya. Hubungan beban kerja (X1) dengan burnout anggota Brimob (Y) menunjukkan nilai kekuatan korealsi sebesar $41.4 \%$, artinya semakin tinggi beban kerja maka semakin meningkat burnout anggota Brimob dan sebaliknya.

Salah satu faktor yang mempengaruhi burnout yaitu beban kerja. Menurut Sari (2015) beban kerja merupakan intensitas pekerjaan yang meliputi jam kerja, jumlah individu yang harus dilayani, serta tanggung jawab yang harus dipikul. Beban kerja secara kualitatif dilihat dari kesulitan pekerjaan tersebut untuk dikerjakan. Hart dan Staveland (dalam Prijayanti, 2015) mendefinisikan beban kerja sebagai perbedaan antara kemampuan karyawan dengan tuntutan tugas yang di terima. Beban kerja itu dapat berupa beban kerja fisik dan beban kerja mental. Everly (dalam Munandar, 2001) mengatakan bahwa beban kerja adalah keadaan dimana pekerja dihadapkan pada tugas yang harus diselesaikan pada waktu tertentu. Kategori lain dari beban kerja adalah kombinasi dari beban kerja kuantitatif dan kualitatif. Beban kerja secara kuantitatif yaitu timbul karena tugas-tugas terlalu banyak atau sedikit, sedangkan beban kerja kualitatif yaitu jika pekerja merasa tidak mampu melaksanakan tugas atau tugas tidak menggunakan ketrampilan atau potensi dari pekerjaan

Menurut Cooper (dalam Munandar, 2001) secara spesifik, beban kerja dapat dibagi dua, yaitu beban kerja fisik dan mental. Beban fisik cenderung mengarah pada beban yang diterima seorang karyawan dalam suatu pekerjaan yang berkaitan dengan kondisi fisiologisnya, seperti kebisingan, vibrasi (getaran), dan hygiene. Apabila kondisi kerja yang demikian cukup buruk, maka akan terjadi stres kerja dengan gejala fisikal, seperti tekanan darah tinggi, diare, obstipasi, dan lain-lain.

Hard dan Steveland (1988) mendefenisikan beban kerja sebagai perbedaan antar kemampuan karyawan dengan tuntutan tugas yang diterima. Everly (dalam Munandar, 2001) mengatakan bahwa beban kerja adalah keadaan dimana pekerjaan dihadapkan pada tugas yang harus diselesaikan pada waktu tertentu. Hasil 
penelitian ini menujukan bahwa anggota Brimob yang merasakan memiliki beban kerja yang tergolong sedang, terdapat 48 anggota Brimob atau sekitar $24.48 \%$ dan yang mengalami beban keja pada kategori tinggi. Sebanyak 148 orang atau sekitar $75.52 \%$.

Dalam penelitian yang dilakukan oleh Rizqiansyah (2017) menyebutkan bahwa faktor yang mempengaruhi terjadinya burnout pada karyawan adalah beban kerja yang tinggi. Hart dan Staveland (dalam Prijayanti, 2015) mendefinisikan beban kerja sebagai perbedaan antara kemampuan karyawan dengan tuntutan tugas yang di terima. Beban kerja itu dapat berupa beban kerja fisik dan beban kerja mental. Menurut Cooper (dalam Munandar, 2001) secara spesifik, beban kerja dapat dibagi dua, yaitu beban kerja fisik dan mental. Beban fisik cenderung mengarah pada beban yang diterima seorang karyawan dalam suatu pekerjaan yang berkaitan dengan kondisi fisiologisnya, seperti kebisingan, vibrasi (getaran), dan hygiene. Apabila kondisi kerja yang demikian cukup buruk, maka akan terjadi stres kerja dengan gejala fisikal, seperti tekanan darah tinggi, diare, obstipasi, dan lain-lain.

Beban kerja yang diterima oleh karyawan dalam pekerjaannya akan meningkatkan burnout yang tinggi pada pekerja itu sendiri. Menurut Hart dan Staveland (1998) aspek-aspek beban kerja adalah: physical demand, effort, mental demand, temporal demand, performance, frustation level. Aspek physical demand memiliki arti besarnya aktifitas fisik yang dibutuhkan dalam melakukan tugas seperti menarik, memutar, mengontril dan lainnya. Effort, yaitu usaha yang dikeluarkan secara fisik dan mental yang dibutuhkan untuk mencapai level performansi karyawan.
Mental demand, yaitu besarnya aktifitas mental dan perseptual yang dibutuhkan untuk melihat, mengingat dan mencari. Pekerjaan tersebut mudah atau sulit, sederhana atau kompleks, longgar atau ketat. Temporal demand, yaitu jumlah tekanan yang berkaitan dengan waktu yang dirasakan selama pekerjaan berlangsung. Pekerjaan perlahan atau santai atau cepat atau melelahkan. Frustation level, yaitu seberapa tidak aman, putus asa, tersinggung, terganggu, dibandingkan dengan perasaan aman, puas, nyaman, dan kepuasan diri yang dirasakan. Performance, yaitu seberapa besar keberhasilan seseorang di dalam pekerjaannya dan seberapa puas dengan hasil kerjanya.

Faktor lain yang mempengaruhi burnout adalah efikasi diri. Bandura (1997) self-efficacy merupakan keyakinan individu mengenai kemampuan dirinya dalam melakukan tugas atau tindakan yang diperlukan untuk mencapai hasil tertentu. Self-efficacy ini dapat menggerakkan motivasi, kemampuan kognitif, mengurangi ketegangan emosi dan tindakan, yang diperlukan untuk memenuhi tuntutan situasi. Sehingga ketika seseorang memiliki efikasi yang rendah, dia akan kurang mampu untuk menghadapi suatu masalah atau tugas tertentu. Pernyataan tersebut didukung dengan hasil analisis data yang ditunjukkan oleh koefisien korelasi (rxy) dengan nilai signifikansi (p) $0.000<0,05$. Dan koefisien korelasi (rxy) sebesar 0.90. Sehingga dapat disimpulkan bahwa ada hubungan efikasi diri dengan burnout pada anggota Brimob. Dari hasil penelitian ditemukan Koefisien korelasi (rxy) sebesar 0,90 dan yang memiliki arti bahwa kekuatan hubungan efikasi diri dengan burnout sebesar 90\%,. 
Pada penelitian yang dilakukan oleh Lailani (2012) menemukan hubungan yang signifikan efikasi diri terhadap burnout pada perawat. Menurut Bandura (dalam Sulistyawati, 2010) aspek-aspek efikasi diri, yaitu kekuatan, generalisasi dan tingkatan. Kekuatan adalah individu yang memiliki level yang tinggi merasa bahwa dirinya memiliki kemampuan menguasai permasalahan yang sulit, sedangkan individu yang memiliki level yang rendah meyakini bahwa dirinya hanya mampu menyelesaikan tugas-tugas yang sederhana. Generalisasi, yaitu individu dengan efikasi diri tinggi merasa bahwa dirinya memiliki kemampuan untuk dapat bertindak dalam situasi apapun, sedangkan individu dengan efikasi diri rendah merasa bahwa dirinya hanya memiliki kemampuan untuk bertindak pada situasi yang terbatas. Kekuatan, yaitu individu dengan kekuatan efikasi diri yang tinggi sangat yakin akan kemampuan dirinya, mereka akan bertahan dalam usaha menghadapi masalah yang sulit, mampu menyelesaikan masalah yang penuh rintangan, dan ketekunan yang besar akan berhasil dalam melakukan tugasnya, sebaliknya, mereka yang memiliki kekuatan efikasi diri yang rendah akan merasa bahwa kemampuannya lemah dan akan mudah terguncang apabila menghadapi rintangan dalam melakukan tugasnya.

Hasil penelitian ini menunjukan anggota Brimob yang memiliki efikasi diri rendah ada sejumlah 3 orang tau sekitar $1.7 \%$, sementara yang memiliki efikasi diri sedang terdapat 137 orang atau sekitar $69.8 \%$ dan yang memiliki efikasi diri tinggi sebanyak 56 orang atau sekitar $28.5 \%$. Sehingga secara keselurruhan dapat disimpulkan bahwa efikasi diri anggota Brimob dalam kategori sedang.
Self-efficacy sangat penting dalam kehidupan manusia, karena self-efficacy banyak menentukan dan mempengaruhi aspek-aspek kehidupan kita, diantaranya potensi menangani burnout. Self-efficacy sangat penting dalam mengatasi berbagai permasalahan yang dapat menyebabkan seseorang merasa tertekan dan burnout. Dalam hal ini, mengatasi burnout yang dirasakan anggota BRIMOB dalam pekerjaannya. Self-efficacy sangat diperlukan oleh seorang anggota BRIMOB karena dapat mempengaruhinya dalam menyelesaikan berbagai permasalahan yang berkaitan dengan bidang tuntutan pelaksanaan tugas dan hak-hak anggota yang sering berbenturan. Anggota dengan self-efficacy yang tinggi mampu mengelola kejenuhan kerja dengan mengarahkan mereka pada usaha penyelesaian masalah. Sebaliknya, anggota yang memiliki selfefficacy yang rendah akan mencoba untuk menghindari berurusan dengan segala permasalahan dalam pekerjaan (Maharani, 2011).

Secara bersamaan hasil penelitian ini menunjukan bahwa ada hubungan antara beban kerja dan efikasi diri dengan burnout pada anggota Brimob, hal ini didukung dengan hasil analisis data yang ditunjukkan oleh nilai signifikansi (p) sebesar $0.000<$ 0.05 sedangkan nilai koefisien korelasi (rxy) $=0.429$. Burnout merupakan perubahan sikap dan perilaku dalam bentuk reaksi menarik diri secara psikologis dari pekerjaan, seperti menjaga jarak dari orang lain maupun bersikap sinis dengan mereka, membolos, sering terlambat dan keinginan pindah kerja sangat kuat. Hal ini terjadi dikarenakan perusahaan atau organisasi tidak memikirkan kualitas kehidupan kerja para karyawannya, berupa kenyamanan baik secara psikologis maupun fisik yang harus 
didapatkan oleh para karyawan atau pekerjanya. Apabila hal tersebut tetap terjadi, tidak hanya di dalam kehidupan bekerja saja yang akan mengalami permasalahan yang dipengaruhi oleh burnout, tetapi di dalam kehidupannya sehari-hari terutama hubungan dengan teman dan keluarganya akan mengalami kesenjangan atau masalah yang disebabkan dari perubahan atau goncangan emosi di dalam diri seorang pekerja yang mengalami burnout.

Penelitian yang dilakukan oleh Sari (2015) menemukan bahwa semakin tinggi tingkat burnout karyawan maka akan menurunkan daya semangat kerja karyawan pada perusahaan. Selanjutnya Penelitian Ramadhoni dkk (2015) mengungkapkan bahwa tingginya burnout pada karyawan akan berpengaruh pada cara karyawan bekerja dalam perusahaan. Aspek-aspek burnout dalam penelitian ini menggunakan aspek-aspek berdasarkan aspek-aspek dari Maslach \& Jackson (dalam Cooper, Schabarcq, \& Winnubust, 1996), yaitu: kelelahan emosional, depersonalisasi, dan reduced personal accomplishment.

Faktor yang mempengaruhi burnout yaitu beban kerja. Menurut Sari (2015) beban kerja merupakan intensitas pekerjaan yang meliputi jam kerja, jumlah individu yang harus dilayani, serta tanggung jawab yang harus dipikul. Beban kerja secara kualitatif dilihat dari kesulitan pekerjaan tersebut untuk dikerjakan. Hart dan Staveland (dalam Prijayanti, 2015) mendefinisikan beban kerja sebagai perbedaan antara kemampuan karyawan dengan tuntutan tugas yang di terima. Beban kerja itu dapat berupa beban kerja fisik dan beban kerja mental. Everly (dalam Munandar, 2001) mengatakan bahwa beban kerja adalah keadaan dimana pekerja dihadapkan pada tugas yang harus diselesaikan pada waktu tertentu. Kategori lain dari beban kerja adalah kombinasi dari beban kerja kuantitatif dan kualitatif. Beban kerja secara kuantitatif yaitu timbul karena tugas-tugas terlalu banyak atau sedikit, sedangkan beban kerja kualitatif yaitu jika pekerja merasa tidak mampu melaksanakan tugas atau tugas tidak menggunakan ketrampilan atau potensi dari pekerjaan

Menurut Cooper (dalam Munandar, 2001) secara spesifik, beban kerja dapat dibagi dua, yaitu beban kerja fisik dan mental. Beban fisik cenderung mengarah pada beban yang diterima seorang karyawan dalam suatu pekerjaan yang berkaitan dengan kondisi fisiologisnya, seperti kebisingan, vibrasi (getaran), dan hygiene. Apabila kondisi kerja yang demikian cukup buruk, maka akan terjadi stres kerja dengan gejala fisikal, seperti tekanan darah tinggi, diare, obstipasi, dan lain-lain.

Faktor lain yang mempengaruhi burnout yaitu efikasi diri. Menurut Bandura (1997) self-efficacy merupakan keyakinan individu mengenai kemampuan dirinya dalam melakukan tugas atau tindakan yang diperlukan untuk mencapai hasil tertentu. Self-efficacy ini dapat menggerakkan motivasi, kemampuan kognitif, mengurangi ketegangan emosi dan tindakan, yang diperlukan untuk memenuhi tuntutan situasi. Sehingga ketika seseorang memiliki efikasi yang rendah, dia akan kurang mampu untuk menghadapi suatu masalah atau tugas tertentu. Menurut Bandura (1997) reaksi stres pada seseorang, terjadi karena rendahnya self-efficacy orang tersebut untuk mengontrol ancaman dari lingkungan yang tidak menyenangkan, sehingga ketika dihadapkan dengan situasi yang kurang 
menyenangkan, mereka tidak mampu berfungsi dengan baik.

Baron dan Byrne (2003)

mengemukakan bahwa self-efficacy merupakan penilaian individu terhadap kemampuan atau kompetensinya untuk melakukan suatu tugas, mencapai suatu tujuan dan menghasilkan sesuatu. Schultz (dalam Hartawati \& Mariyanti, 2014) mendefinisikan self-efficacy sebagai perasaan kita terhadap kecukupan, efisiensi, dan kemampuan kita dalam mengatasi kehidupan. Menurut Woolfolk (2004), selfefficacy adalah penilaian individu terhadap dirinya sendiri atau tingkat keyakinan mengenai seberapa besar kemampuannya dalam mengerjakan suatu tugas tertentu untuk mencapai hasil tertentu.

Self-efficacy sangat penting dalam kehidupan manusia, karena self-efficacy banyak menentukan dan mempengaruhi aspek-aspek kehidupan kita, diantaranya potensi menangani burnout. Self-efficacy sangat penting dalam mengatasi berbagai permasalahan yang dapat menyebabkan seseorang merasa tertekan dan burnout. Dalam hal ini, mengatasi burnout yang dirasakan anggota brigade mobile dalam pekerjaannya. Self-efficacy sangat diperlukan oleh seorang anggota brigade mobile karena dapat mempengaruhinya dalam menyelesaikan berbagai permasalahan yang berkaitan dengan bidang tuntutan pelaksanaan tugas dan hak-hak anggota yang sering berbenturan. Anggota dengan selfefficacy yang tinggi mampu mengelola kejenuhan kerja dengan mengarahkan mereka pada usaha penyelesaian masalah. Sebaliknya, anggota yang memiliki selfefficacy yang rendah akan mencoba untuk menghindari berurusan dengan segala permasalahan dalam pekerjaan (Maharani, 2011).
Dari hasil penelitian ini maka ditemukan tingkat burnout pada anggota brigade mobile kepolisian daerah Medan Sumatera Utara terdapat sekitar 174 orang atau sebanyak $88.7 \%$, yang mengalami burnout dalam tingkat sedang dan sebanyak 22 orang atau sebesar $11.3 \%$ yang mengalami burnout dalam kategori tinggi.

\section{Kesimpulan}

Berdasarkan hasil yang telah diperoleh dalam penelitian ini, maka dapat disimpulkan hal-hal sebagai berikut:

1. Ada hubungan positif yang signifikan antara beban kerja dan dengan burnout pada anggota satuan brigade mobile kepolisian Sumatera Utara.

2. Ada hubungan positif yang signifikan antara efikasi diri dengan burnout pada anggota satuan brigade mobile kepolisian Sumatera Utara.

3. Ada hubungan positif yang signifikan antara beban kerja dan efikasi diri dengan burnout pada anggota satuan brigade mobile kepolisian Sumatera Utara.

4. Hasil lain diperoleh dari penelitian ini, yakni diketahui bahwa subjek penelitian ini yaitu anggota satuan brigade mobile kepolisian Sumatera Utara, memiliki burnout yang tergolong rendah, beban kerja yang rendah, dan efikasi diri yang juga tergolong tinggi. 
Adicondro, N., \& Purnamasari, A. 2011. Efikasi diri, dukungan sosial keluarga dan self-regulated learning pada siswa kelas VIII. Humanitas, 7, (1), 17-27.

Alwisol. 2005. Psikologi kepribadian. Malang: Penerbit Universitas Muhammdiyah.

Arikunto, S. 2007. Prosedur penelitian, suatu pendekatan praktik. Jakarta: Renika Cipta.

Azwar, S. 2009. Reliabilitas dan validitas. Yogyakarta: Sigma Alpha.

Bandura, A. 2007. Self-efficacy, the exercise of control. New York: W.H. Freeman and Company.

Baron, R. A., \& Byrne, D. E. 2003. Psikologi sosial. Jakarta: Erlangga.

Baron, R. A., Greenberg, J. 1990. Behaviours in organization: Understanding and managing the human side of work. New York: Allyn \& Bacon.

Cooper, C. N., Schabarcq, M. J., \& Winnubst, J. A. M. 1996. Handbok of work and heath psychology. United States: John Wiley \& Sons Ltd.

Farber, B. A. 1991. Crisis in education: Stress and burnout in the American teacher. San Francisco: Jossey Bass Publishers.

Gold, Y., \& Roth, R. 2005. Teacher managing stress and preventing burnout. London: The Falmer Press.

Khan, A., Fleva, E., \& Qazi, T. 2015. Role of self-esteem and general self-efficacy in teachers' efficacy in primary schools. Scientific Research Publishing Psychology, 6, 117-125.
Lailani, F. 2012. Burnout pada perawat ditinjau dari efikasi diri dan dukungan sosial. Talent Psikologi, 1, (1), 66-86.

Lucia, D. D. 2017. Faktor-faktor yang mempengaruhi employee engagement dengan Psychological capital sebagai mediator dan management leadership sebagai moderator. Disertasi.

Maharani, D. R. 2011. "Hubungan antara self-efficacy dengan burnout pada guru sekolah dasar negeri X di kota Bogor. Tesis. (Tidak dipublikasi).

Maslach, C., \& Goldberg, J. 1998. Prevention of burnout: New perspective. Apply and Preventive Psychology, 7, 63-74.

Maslach, C. 2003. Burnout: The cost of caring. Englewood Cliffs: ISHK.

Munandar, A. S. 2001. Psikologi industri dan organisasi. Jakarta: UI Press.

Hart, S. G., Staveland, L. E. 1998. Development of NASA-TLX (Taks load index) result of empirical and theoretical research. Amsterdam: North-Holland.

Hartawati, D., \& Mariyanti, S. 2014. Hubungan antara self-efficacy dengan burnout pada pengajar taman kanakkanak sekolah "X" di Jakarta. Jurnal Psikologi, 12, (2), 54-60.

Ormrod, J. E. 2008. Human learning (5th ed). Upper Saddle River, NJ: Pearson Merrill Prentice Hall.

Pangastiti, N. K. 2011. Analisis pengaruh dukungan sosial keluarga terhadap burnout pada perawat kesehatan di Rumah Sakit Jiwa.

28 | Psychophedia Jurnal Psikologi Universitas Buana Perjuangan Karawang 
Prijayanti, I. 2015. Pengaruh beban kerja dan dukungan sosial terhadap burnout pada Karyawan PT. X.

Priyatno, D. 2012. Cara kilat belajar analisis data dengan SPSS 20. Yogyakarta: Penerbit Andi.

Puspitasari, D. A., \& Handayani, M. M. 2014. Hubungan tingkat self-efficacy guru dengan tingkat burnout pada guru sekolah Inklusif di Surabaya. Jurnal Psikologi Pendidikan dan Perkembangan. 3, (1).

Rahman, U. 2007. Mengenal burnout pada guru. Jurnal Lentera Pendidikan, 10, (2), 216-227.

Rizqiansyah, M. Z. A. 2017. Hubungan antara beban kerja fisik dan beban kerja mental berbasis ergonomi terhadap tingkat kejenuhan kerja pada karyawan PT. Jasa Marga (PERSERO) Tbk cabang Surabaya Gempol. Jurnal Sains Psikologi, 6, (1), 37-42.

Romadhoni, L. C., Asmony, T., Suryatni, M. 2015. Pengaruh beban kerja, lingkungan kerja, dan dukungan sosial terhadap burnout pustakawan di kota Mataram. Khizanah Al-Hikmah, 3, (2), 125-145.

Sari, N. L. P. D. Y. 2015. Hubungan beban kerja terhadap burnout syndrome pada perawat pelaksana ruang intermediet RSUP Sanglah. Jurnal Dunia Kesehatan, 5, (2), 87-92.

Schaufeli, W. B., \& Bakker, A. B. 2004. Job demans, job resources, and their relationship with burnout and engagement: A multi sampel study. Journal of Organizational Behavior, 25, 293-315.
Schaufeli, W. B., \& Buunk, B.P. 1996. Professional burnout. Handbook of Work and Healthy Psychology. New York: John Wiley \& Son Ltd.

Schultz, D. P., \& Schultz, S. E. 2010. Psychology and work today: A introduction to industrial and organizational psychology. Tenth Edition. USA: Pearson Education.

Schiffman. \& Kanuk. 2004. Perilaku konsumen. Edisi 7. Jakarta: Prentice Hall.

Sugiyono. 2006. Metode penelitian kuantitatif, kualitatif dan $R \& D$. Bandung: Alfabeta.

Sugiyono. 2014. Statistik untuk penelitian. Bandung: ALFABETA.

Sulistyawati. 2010. Hubungan antara dukungan sosial dengan self-efficacy mahasiswa dalam menyusun skripsi. Jurnal Psikologi Sosial, 1, (1).

Swasti, K. G., Ekowati, W., Rahmawati, E. 2017. Faktor-faktor yang mempengaruhi burnout pada wanita bekerja di kabupaten Banyumas. Jurnal Keperawatan Soedirman, 12, (3), 190198.

Tarwaka. 2011. Ergonomi industri. Solo: Harapan Press.

Tetrich. \& Quich. 2002. Job related burnout, occupational health psychology. USA: American Assosiation Psychology.

Wahyono, T. 2004. Peningkatan kesiapan kerja melalui pelatihan efikasi diri dalam bidang pekerjaan pada calon tenaga kerja. Jurnal Psikologika, 18, 54-63. 
Wilson, A., \& Kim, W. 2016. The effects of concept mapping and academic self-efficacy on mastery goals and reading comprehension achievement. International Education Studies. 9, (3), 12-23.

Woolfolk. 2004. Educational psychology. Boston: Pearson Education Inc 